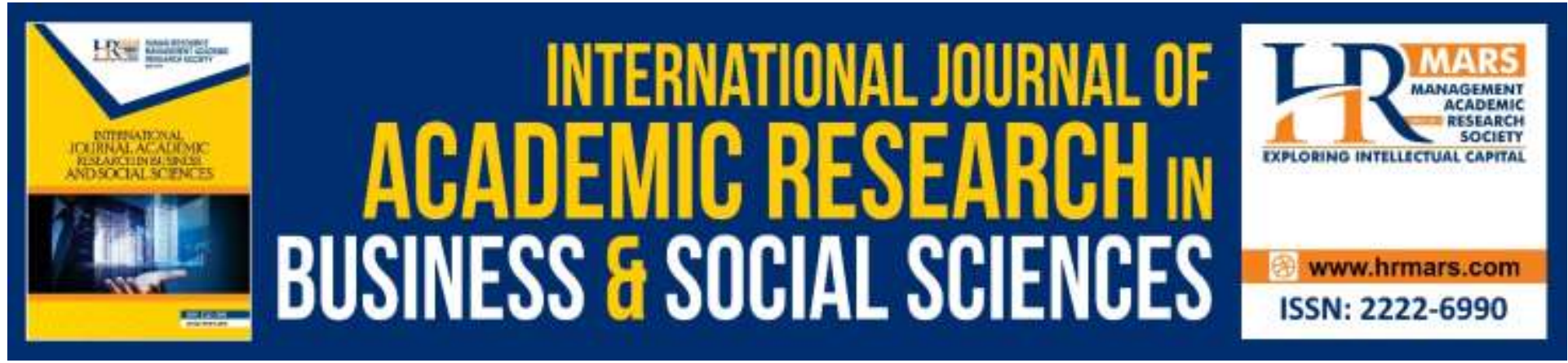

\title{
The Effect of Decentralization, Characteristics of Management Accounting Information on Managerial Performance with Locus of Control as the Moderating Variable
}

\author{
Alamsa, Amiruddin, Syarifuddin Rasyid
}

To Link this Article: http://dx.doi.org/10.6007/IJARBSS/v9-i9/6287

DOI: 10.6007/IJARBSS/v9-i9/6287

Received: 22 June 2019, Revised: 10 July 2019, Accepted: 28 August 2019

Published Online: 23 September 2019

In-Text Citation: (Alamsa, Amiruddin, \& Rasyid, 2019)

To Cite this Article: Alamsa, Amiruddin, \& Rasyid, S. (2019). The Effect of Decentralization, Characteristics of Management Accounting Information on Managerial Performance with Locus of Control as the Moderating Variable. International Journal of Academic Research in Business and Social Sciences, 9(9), 238-251.

Copyright: (C) 2019 The Author(s)

Published by Human Resource Management Academic Research Society (www.hrmars.com)

This article is published under the Creative Commons Attribution (CC BY 4.0) license. Anyone may reproduce, distribute, translate and create derivative works of this article (for both commercial and non-commercial purposes), subject to full attribution to the original publication and authors. The full terms of this license may be seen at: http://creativecommons.org/licences/by/4.0/legalcode

Vol. 9, No. 9, 2019, Pg. 238 - 251

Full Terms \& Conditions of access and use can be found at http://hrmars.com/index.php/pages/detail/publication-ethics 


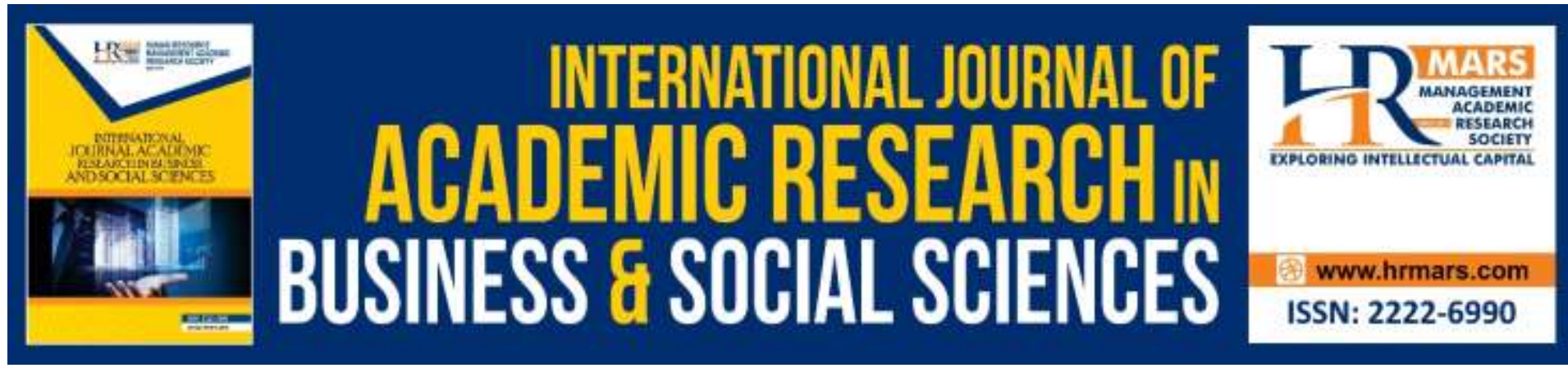

\title{
The Effect of Decentralization, Characteristics of Management Accounting Information on Managerial Performance with Locus of Control as the Moderating Variable
}

\author{
Alamsa $^{1}$, Amiruddin $^{2}$, Syarifuddin Rasyid ${ }^{3}$ \\ ${ }^{1}$ Master of Accounting, Faculty of Economics and Business, Hasanuddin University, \\ 2,3 Accounting Department, Faculty Economic and Business, Hasanuddin University. \\ Email: Alamsa1179@gmail.com
}

\begin{abstract}
This study aims to provide a review of the effect decentralization, characteristics of management accounting Information on managerial performance with locus of control As the moderating variable. The research object in this study was the manager of PT Telkom Witel Sul-sel and PT Multi trading Pratama. The total population was 63 manager and the technique of determining the sample uses a census method, that was, the entire population were used as a research sample. In this study the method used was explanatory research. Data collection used a questionnaire instrument. Data were analyzed using Moderated Regression Analysis (MRA) with the help of software SPSS 23 . The hypotheses proposed were as many as 4 (four). The result show that (1) decentralization has a significant effect on managerial performance (2) characteristics information accounting management has a significant effect on managerial performance (3) locus of control does not moderate the relationship of decentralization on managerial performance (4) locus of control moderates and weakens the relationship of characteristics information accounting management on managerial performance.
\end{abstract}

Keywords: Decentralization, Characteristics of Management Accounting Information, Locus of Control, Managerial Performance.

\section{Introduction}

In improving managerial performance, human resources become the most important aspect in an organization; this aspect can bring the most significant impact in increasing organizational productivity (Zammuto and Bedeian, 1991). Performance appraisal carries an important role to know or measure the success of an organization. But in reality these conditions are still not getting enough attention from some companies, because they are still oriented to the benefits and timely completion of performance by not paying attention to the results of their performance or only pay attention to economic aspects to the exclusion of non-economic aspects. This is certainly not suitable to be applied in the era of globalization, where business competition is getting tougher. Very tight competition indirectly requires the 
company's management to be more observant in setting strategies and utilizing existing capabilities so that the company is able to survive and excel in competition and be able to face all existing problems (Supriono, 1992).

According to a study conducted by Towers Watson (2015) said that half of managers in the world are less reliable and less effective in achieving work goals. A study published in the book Effective Managers: Your Critical Link to Successful Strategy Execution says that many managers lack introspection about the needs of work teams that cause them to neglect their work. The results of studies from a number of companies show that many companies in the world experience a crisis of employee effectiveness. Companies that participated in 2014 Talent Management and Rewards found that only half the managers were considered to be working optimally. The rest, failed. This situation is caused by bad habits that are often encountered in a number of managers who are less responsive in executing ideas or suggestions from subordinates.

Organizations that are growing rapidly, both operational activities and business networks will tend to use business unit strategies to overcome operational complexity. Efforts to improve and enhance the effectiveness and productivity of an organization need a decentralized organizational structure. Decentralized organizations are those whose decisionmaking is not only left to top managers, but is handed down to the lower levels to make and implement important decisions relating to their area of responsibility. With decentralization, managers are given the right to make decisions by their superiors and implement those decisions. On the other hand, the manager will also be responsible for the decisions that he has taken. Thus, managers need information as a basis for determining decisions, so that the policies they take are of high quality and can be accounted for. Because in organizations that adhere to a centralized system, middle managers and supervisor managers or subordinates only carry out tasks or orders from their superiors and are not authorized to make decisions.

Miah and Mia (1996) state that the delegation and responsibility of top management to the lower level of management to make decisions, brings the consequences of greater responsibility for lower level management towards the implementation of decisions made to achieve organizational goals. The importance of decentralization as a formal structural arrangement has long been emphasized in organizations. Conditionally, management accounting plans are oriented to the organization's internal financial information based on historical data. Increased tasks in solving problems faced by management, the management accounting design is not only oriented to data that are non-financial. The existence of interdependence in the design of management accounting will increase the complexity of the tasks faced by managers, the availability of management accounting information will help coordinate the tasks of interdependent units.

Characteristics of management accounting information as one of the products of management accounting plays a role in helping predict the consequences that may occur for various activities as planning, controlling, and making decisions. The presence of information will also increase the ability of managers to understand the actual state of the environment and function also in identifying relevant activities. The characteristics of useful information based on the perceptions of managers as decision makers are categorized in four characteristics namely broad scope, timeliness, aggregation, and information integrity (Chenhall and Morris, 1986). Management accounting itself is prepared by a company or organization in order to produce information that is useful in management decision making. Generally the information used by management revolves around costs, so it is commonly 
referred to as cost accounting. In addition to requiring cost accounting for cost of goods, management accounting also requires data for monitoring and analysis of costs made in the form of standards and others (Bayuaji, 2009). Information needs are provided. Information of a company in the business world has several main objectives (Hansen and Mowen, 2000), namely providing information supporting decisions, providing information that supports the daily process and providing accounting information that contains wealth information.

The company's low performance, caused by its dependence on the company's management accounting system which failed in determining the right target, performance measurement (Kaplan, 1990; Banker et al. 1993). This fact refers to the contingency approach which is based on the premise that there is no universal management accounting system that is always appropriate to be applied to all organizations in every situation, contingency approach is needed to evaluate environmental factors (intensity competition, strategy, and environmental uncertainty) that can cause a more effective management accounting system but the management accounting system depends also on the conditional factors that exist within the organization.

Organizational performance is influenced by several factors both related to oneself and those related to the environment of agencies or organizations. Managerial information needs are also influenced by personality factors as indicated by locus of control. Locus of control has someone's personal responsibility for what happens to them. Locus of control also illustrates that individual beliefs can influence events related to individual life. Brownell (1982) and Frucot and Shearron (1991) research on the relationship between locus of control and management control. The results of his study indicate that there is a positive influence between individuals who have internal locus of control and managerial performance. Rahman (2002) explains that the locus of control cannot function as a moderation in the relationship between decentralization in making decisions and the use of accounting controls with the fulfillment of business unit performance. Locus of control is one of the personality characteristics found in a person that influences how the individual interprets or perceives the event he is facing.

This research is a replication of the research conducted by Rahman (2002) and Nugraeni (2013). This research was conducted to examine managerial performance in increasing organizational productivity. The difference between this research and the previous research is that it includes management information characteristic variables. The reason for the inclusion of management information characteristics variables is that the characteristics of management information will be effective if the information needed is in accordance with the user's information so that it can affect managerial performance.

\section{Literature Review Theory Contingency}

Contingency theory states that all components of an organization must have a match or compatibility between one another. The contingency approach to management accounting is based on the premise that no universal management accounting system is always appropriate to be applied to all organizations in all circumstances (Outley, 1980). This proves that the design with various components of management accounting system information depends on special contingency conditions. Contingency theory can be used to analyze design and management accounting systems to provide information that companies can use for various purposes and to face competition. 
The contingency approach used attracts many researchers because they want to find out whether the level of reliability of the management accounting system will always have the same effect on each condition or not. Based on contingency theory, it is assumed that there are other situational factors that might interact with each other in influencing certain conditions.

\section{Theory Planned of Behavior (TPB)}

Theory of planned behavior (TPB) is a development of the theory of reasoned action (TRA) which was developed in advance by Ajzen and Martin Fishbein in 1975. This theory assumes that a person's behavior is not only controlled by oneself (full individual control), but also requires control, namely the availability of resources and opportunities and even certain skills, so it is necessary to add the concept of behavioral control (perceived behavioral control) which is perceived to affect intentions and behavior. Theory of planned behavior explains how certain behaviors can be predicted through the determinant of the behavior.

Theory of planned behavior refers to the theory which states that behavior is a function of prominent information or beliefs about the behavior. People can have a variety of beliefs about a behavior, but when faced with a particular event, only a few of these beliefs arise to influence behavior. It is this little belief that stands out in influencing individual behavior.

\section{Decentralization}

Decentralization is generally indicated by the level of decision making that occurs in organizations. The higher the level of decentralization, the lower the hierarchy in which decisions will be made (Chia, 1995). With decentralization, top managers delegate authority and responsibility to lower managers with certain strengths. Delegation is given to management (subordinates) who are lower in decision making authority and this will be followed by responsibility for the activities carried out. The authority gives the right to determine the assignment, while the responsibility is the obligation to achieve the specified task (Hellriegel and Slocum, 2011).

Companies that have a responsibility center usually have one of the two decisionmaking approaches to managing their complex and diverse activities, namely centralization and decentralization. Centralized decision making (centralized decision making) various decisions made at the level of top managers and managers at the lower levels are responsible for implementation. Whereas decentralization decision making allows managers at lower levels to make and implement decisions related to their area of responsibility. In an effort to improve overall efficiency, many companies choose a decentralized way.

\section{Management Accounting Information}

Management accounting system is a system that can provide or deliver relevant information to management for decision making, planning, and supervision. Management accounting literature, explains that management accounting systems are generalizations of accounting information systems and management information systems. Basically the management accounting system consists of two things, namely broadscope and aggregation. Broadscope information is wide-ranging information that contains dimensions of focus, quantification, and time horizon. While information aggregation is a summary of information according to function, time period, and decision model. 
Management accounting information is an information mechanism of organizational control, and is a fairly effective tool in providing useful information to predict the consequences that might occur and activities that can be done. One of the products produced by the management accounting system is management accounting information is management accounting information such as expenses incurred in the operational department, calculation of production costs, services, activities.

\section{Hypothesis \\ Effects of Decentralization on Managerial Performance}

Decentralization is the transfer of authority and responsibility to managers. The level of delegation itself indicates the extent to which higher management allows lower management to make policies independently (Heller and Yulk, 1969). The authority here is to give understanding as the right to determine the assignment, while responsibility is an obligation to achieve the specified task.

To explain the relationship between decentralization variables and managerial performance in this study, contingency theory developed by (Chenhall, 2003) contingency theory in management control lies between the two extreme Extreme first, management control will be a situation specific model or a control model the right thing will be greatly influenced by the situation at hand. The second extreme is the fact that a management control system can still be generalized to be applied to several different companies. Starting from a contingency approach in the different levels of decentralization allows differences in management information needs. If the organization grows with the participation of many people, it becomes impossible for a top manager to make decisions about everything. To some degree, managers must delegate decisions to lower managerial levels by decentralizing and authorizing.

The existence of decentralized conditions causes managers to have a greater role in decision making and implementation, and is more responsible for the activities of the work units they lead. Decentralization will also cause managers who are subject to an abundance of authority need quality and relevant information to support the quality of decisions. The suitability of information with the needs of decision makers will improve the quality of decisions to be taken, which in turn will improve the performance of managers.

$\mathrm{H} 1$ : Decentralization has an effect on managerial performance.

Effects Characteristics of Management Accounting Information on Managerial Performance Based on the contingency theory in the research method, it is argued that the effectiveness of management accounting system design depends on the existence of a combination of the organization and its environment. Management accounting systems as an organizational control tool and effective tools provide useful information to predict the consequences that might occur in various activities undertaken, where management accounting information systems that have Broad Scope, Timelines, Aggregation, Integration characteristics that can improve manager performance. Managers who have information with these characteristics are generally able to make better plans and be able to achieve the targets set. 
$\mathrm{H} 2$ : The characteristics of management accounting information has an effect on managerial performance.

\section{Decentralization has an Effect on Managerial Performance Moderated with Locus of Control}

The contingency approach can be used to analyze design and management accounting systems to provide information that companies can use for various purposes. The use of contingency factors is based on the possibility of differences in business strategies, and the decentralization that is applied will result in differences in the information needs of management accounting systems which will ultimately affect managerial performance. If the manager has a good locus of control, then the manager's opportunity in making a decision will have a good impact on the manager's performance, or vice versa.

Theory planned of behavior in the context of locus of control is an individual's attitude or belief in his ability to control destiny. Individuals who have high initiative, like to work hard, always try to find problem solving, think effectively, and believe that success starts with oneself is likely to have an internal locus of control, whereas individuals who lack initiative, do not try to solve problems, less effort, and have the belief that success is controlled by external factors is a characteristic of individuals who have an external locus of control

H3 : Decentralization has an effect on managerial performance which is moderated by locus of control.

\section{Characteristics of Management Accounting Information has an Effect on Managerial Performance Moderated with Locus of Control}

A universal management accounting system is always appropriate to be applied to all organizations in every circumstance but the accounting information system depends on the situational factors that exist in the organization. Potential factors that can be used as a rationale for connecting managerial accounting systems with managerial performance are based on the belief that managers understand the nature of their work. In other words, by understanding the nature of their work, they can consider how to use information to be more useful to them and carry out their work effectively. It is hoped that by using the information provided, managers can complete the work effectively which can ultimately improve managerial performance.

In the context of the theory of planed of behavior in the view of managers the controlling factor is outside the control of the organization (external locus of control), then the manager will feel powerless to move the organization to achieve the goals that want achieved in financial performance. According to Nazaruddin (1998) who examined the effect of decentralization, and the characteristics of information in the form of Broad Scope, Timelines, Aggregation and Integration on managerial performance shows that the information characteristics have a positive and significant effect on managerial performance. Thus, managers who have good locus of control with the need for high management information, the possibility of Managerial Performance will Increase.

H4: characteristics of management accounting information has an effect on managerial performance which is moderated by locus of control. 


\section{Methodology of Research}

This study was designed to test hypotheses related to the relationship between variables. The relationship between these variables shows the causality relationship between the variables in the model. Such a model is also called a (causal model). This type of research, when viewed from the objective of the research is (explanatory research). This type of consideration is to analyze the causality relationship between factors that affect managerial performance. Causality is necessary in explanatory research to make inferences that show the influence of independent variables on changes in the value of the dependent variable. The approach used in this research is a quantitative approach, which includes quantitative analysis to test between theory and reality by first establishing a hypothesis then testing with statistical analysis techniques. The time dimension of this research involves a certain time (cross section)

The population in this study was 63 people. The sample is part of the number and characteristics possessed by the population. Determination of the sample used in this study uses a saturated sampling type of sampling technique when all members of the population are used as samples. This is often done if the population is relatively small, less than 30 people. A saturated sample is also called a census, where all members of the population are sampled. The method used by researchers is by giving questionnaires to Telkom Witel Sulsel and PT Multi Trading Pratama (managers) to determine the frequency of the effects of decentralization and characteristics of management accounting information on managerial performance with locus of control as a moderating variable. The model of data analysis and hypothesis testing in this study is the Moderated Regression Analysis with the help of software SPSS 23.

\section{Research Result}

\section{Regression Analysis Before Interacting with Moderating Variables}

Testing the hypothesis in this study using a partial test. This test basically shows how far the influence of partially independent variables on the dependent variable. The null hypothesis $(\mathrm{HO})$ to be tested is whether a parameter $(\beta 1)$ in the model is equal to zero. If the significance value $<0.05$, then the null hypothesis is rejected and an alternative hypothesis is accepted stating that an independent variable partially influences the dependent variable. If the significance value $>0.05$, then the null hypothesis is accepted and the alternative hypothesis is rejected which states that an independent variable partially does not affect the dependent variable.

Table 1 Regression Test Results without Moderating Variables

\begin{tabular}{|l|c|c|c|c|}
\hline $\begin{array}{c}\text { Independent } \\
\text { Variable }\end{array}$ & Coefficient & T & Sig. & Information \\
\hline Constant & 17,400 & & & \\
\hline Decentralization(X1) & 0,233 & 2,025 & 0,048 & Significant \\
\hline KIAM $(X 2)$ & 0,203 & 3,528 & 0,001 & Significant \\
\hline$\alpha=5 \%=0,05$ & \\
R square $=0,301$
\end{tabular}

Source: Data Processed, 2019 
From the table above shows that the coefficient values for all independent variables are positive. This indicates that the influence of decentralized variables and the characteristics of management accounting information is directly proportional to managerial performance variables. The table above also shows that the decentralization variable and the characteristics of management accounting information show a significant influence on managerial performance. This can be seen from the probability value smaller than 0.05 , where the probability value for decentralization is 0.048 , the characteristics of management accounting information is 0.001 . These results indicate that all independent variables have a significant effect on the dependent variable. As for the value of the $\mathrm{R}$ square determination coefficient on the test results above shows the value of 0.301 or $30.1 \%$. These results indicate that managerial performance variables are influenced by $30.1 \%$ decentralization (X1), the characteristics of management accounting information (X2). The remaining $69.9 \%$ is influenced by other variables outside the independent variables examined in this study.

\section{Regression Analysis After Interacting with Moderating Variables}

The results of regression testing after interacting with the moderating variables of interaction between the decentralized variable and the locus of control, the characteristics of management accounting information and the locus of control can be seen in the following table.

\section{Interaction between Decentralization (X1) and Locus of control (X3)}

Regression test results for the interaction between decentralized variables (X1) and Locus of control (X3), can be seen in the following table.

Table 2 Interaction Regression Test Results between Decentralization (X1) and Locus of control (X3)

\begin{tabular}{|l|c|c|c|}
\hline \multicolumn{1}{|c|}{ Variable } & Coefficient & Sig. & Information \\
\hline Constant & 17,938 & & Not significant \\
\hline DES (X1) & 0,076 & 0,915 & Not significant \\
\hline LOC $(X 3)$ & $-0,031$ & 0,943 & Not significant \\
\hline Des $/$ loc Interaction & 0,010 & 0,721 & \\
\hline$\alpha=5 \%=0,05$ & & \\
R square $=0,150$
\end{tabular}

Source: Data Processed, 2019

In the table above the locus of control variable in moderating the effect of decentralization on managerial performance, obtained a probability value of 0.714 . Because the probability value is greater than $5 \%(0.721>0.050)$, then the locus of control partially cannot moderate the effect of decentralization on managerial performance $(\mathrm{Y})$. 


\section{Interaction between Management Accounting Information Characteristics (X2) and Locus} Of Control (X3)

Regression test results for interactions between the variables of Management Accounting Information Characteristics (X2) and Locus of Control (X3), can be seen in the following table.

Table 3 Interaction Regression Test Results between characteristics of management accounting information(X2) and Locus of Control (X3)

\begin{tabular}{|c|c|c|c|}
\hline Variable & Coefficient & Sig. & Information \\
\hline Constant & $-29,247$ & & \\
\hline $\operatorname{KIAM}(X 2)$ & 1,194 & 0,006 & Significant \\
\hline LOC (X3) & 1,872 & 0,017 & Significant \\
\hline $\begin{array}{l}\text { KIAMxloc } \\
\text { Interaction }\end{array}$ & $-0,043$ & 0,017 & Significant \\
\hline $\begin{array}{l}\alpha=5 \%=0,05 \\
\text { R square }=0,263\end{array}$ & & & \\
\hline
\end{tabular}

Source: Data Processed, 2019

In the table above the locus of control variable in moderating the influence of the characteristics of management accounting information on managerial performance obtained a probability value of 0.017 . Because the probability value is less than $5 \%(0.017<0.050)$, then the locus of control partially moderates the influence of the characteristics of management accounting information on managerial performance $(Y)$. The coefficient for the interaction characteristics of management accounting information and locus of control is negative at 0.043. This means that the locus of control variable weakens the influence of the characteristics of management accounting information on managerial performance.

$R$ square determination coefficient on the test results above shows the value of 0.263 or $26.3 \%$. These results indicate that managerial performance variables are influenced by $26.3 \%$ by the characteristics of management accounting information variables after interacting with the locus of control variable. The remaining $73.7 \%$ is influenced by other variables.

\section{Discussions}

\section{Decentralization has an Effect on Managerial Performance}

The results of hypothesis testing indicate that hypothesis 1 submitted was accepted. Thus the hypothesis that decentralization influences managerial performance empirically can be proven. This finding shows that decentralization significantly affected managerial performance at PT Telkom witel Sul-sel and PT Multi trading pratama. These results prove that the organization has optimized the level of decentralization in terms of decision making and policy for people who are at the lower level in an organizational structure, to improve the managerial performance of the company. This means that the higher the decentralization of the company, the better managerial performance will be.

The results of this study are in accordance with the contingency theory by Suartana (2011) which states that contingency theory in a company is closely related to interactions for adjustment and control of the environment to maintain business survival. Systems that 
are designed and used by certain companies may not necessarily be used by other companies. In this case the differences in conditions and environment that causes a different company system. This difference is noted in a (contingency theory) if the organization grows with the participation of many people, it becomes impossible for a top manager to make decisions about everything. To some degree, managers must delegate decisions to lower managerial levels by decentralizing. Therefore, a decentralized organization will make it easier for managers to make decisions in which managerial performance will be effective and efficient.

On the other hand the manager will also be responsible for the decisions that he has taken. Decentralized organizational structure is generally aimed at making decisions that occur within the organization. Decentralization will show a degree of autonomy delegated to managerial so that managerial has greater responsibility for planning and controlling operational activities and requires more information, thus managers need information as a basis for determining decisions, so that the policies they take are of high quality and can be accounted for.

\section{The Characteristics of Management Accounting Information has an Effect Managerial Performance}

The results of hypothesis testing indicate that hypothesis 2 submitted was accepted. Thus the hypothesis which states that the characteristics of management accounting information empirically influences managerial performance can be proven. This finding shows that the characteristics of management accounting information significantly influence managerial performance at PT Telkom witel Sul-sel and PT Multi trading pratama. These results prove that management accounting information needs in the form of broad scope, integration, aggregation and timelinnes are available for managers that are useful for making decisions, making planning and as a management control system, meaning that quality management accounting information will improve the company's managerial performance.

The results of this study are in accordance with the contingency theory by (Outley, 1980 ) states that all components of an organization must have a match or suitability between one another. The contingency approach to management accounting is based on the premise that no universal management accounting system is always appropriate to be applied to all organizations in every circumstance Contingency theory can be used to analyze the design and management accounting system to provide information that companies can use for various purposes and to face competition, information systems that produce outputs using inputs and various processes needed to meet management objectives.

This process can be described through various activities such as gathering, measuring, storing, analyzing, reporting, and managing information. Outputs include special reports, cost of products, customer costs, budgets, performance reports, and personal communication (Hansen and Mowen, 2000). Management accounting system planning is part of the organizational control system that needs attention, so it is expected to make a positive contribution in supporting the success of the organization's control system. One function of the management accounting system is to provide an important source of information to help managers control their activities. 


\section{Locus of Control Moderates the Effect of Decentralization on Managerial Performance}

The test results show that the proposed hypothesis was rejected. The meaning of locus of control moderating the relationship between decentralization and managerial performance cannot be proven. The findings of this study indicate that the level of decentralization owned by the company, although supported by locus of control, does not yet provide a meaningful relationship to the managerial performance of PT Telkom Witel SulCell and PT Multi Trading Pratama.

The theory used in the initial hypothesis formulation is the TPB theory, where one of the dimensions of the TPB theory is that trust control can facilitate or hinder the performance of behaviors and perceived power of factors that support or inhibit individual behavior in this case locus of control cannot be proven when associated with decentralization. The results of this study are also supported by Rahman (2002) and Nugraeni (2013) who have not yet succeeded in showing that the locus of control is able to moderate the decentralization of managerial performance. Based on this, it can be concluded that the locus of control does not significantly moderate the relationship between decentralization and managerial performance.

\section{Locus of Control Moderates the Effect of Management Accounting Information Characteristics on Managerial Performance}

The test results show that the proposed hypothesis is accepted. The meaning of locus of control moderate the relationship between the characteristics of management accounting information on managerial performance can be proven. This finding also shows that the locus of control can significantly weaken the influence of the characteristics of management accounting information on managerial performance. This shows that the high locus of control weakens the influence of management accounting information characteristics on PT Telkom witel Sul-sel and PT Multi trading pratama.

The results of this study are in line with TPB theory on the third dimension of the theory, which is perceived control in producing a behavior (Ajzen, 1991). One that is included is the characteristics of management accounting information. The characteristics of management accounting information are considered as controls that are perceived as trust controls that can facilitate or hinder the performance of behaviors and the perceived strength of factors that support or hinder a person's behavior. And, with the control that is understood by the manager of the work done to make decisions more easily related to management accounting information available. Individuals who have high initiative, like to work hard, always trying to find problem solving, think effectively, and believe that success starts from oneself locus of internal control. Based on the results of this study, it can be concluded that the locus of control significantly moderates and weakens the influence of the characteristics of management accounting information on managerial performance. This means that the higher the locus of control will affect and weaken the relationship of the characteristics of management accounting information to managerial performance.

To the best of the researchers' knowledge, there is no literature or other research that specifically discusses the relationship between locus of control moderation that is associated with the characteristics of management accounting information on managerial performance. But at least this research has indicated there is a moderation relationship and could be the basis for further research. 


\section{Conclusions}

Based on the results of hypothesis testing and discussion of the effects of decentralization and the characteristics of management accounting information on managerial performance with moderated locus of control, the following conclusions can be drawn.

1. Decentralization has a positive effect on managerial performance. This means that an increase in decentralization will be followed by an increase in managerial performance. The results of this test confirm the contingency theory, that is, systems that are designed and used by certain companies may not necessarily be used by other companies. In this case the differences in conditions and environment that causes a different company system.

2. The characteristics of management accounting information have a positive effect on managerial performance. This means that an increase in the characteristics of management accounting information will be followed by an increase in managerial performance. The results of this test confirm the contingency theory, which states that all components of an organization must have a match or compatibility between one another. The contingency approach to management accounting is based on the premise that no universal management accounting system is always appropriate to be applied to all organizations in all circumstances.

3. Locus of control does not moderate the effect of decentralization on managerial performance. This means that the level of decentralization owned by the company, although supported by locus of control, does not yet provide a meaningful relationship to managerial performance.

4. Locus of control moderates and weakens the relationship of the characteristics of management accounting information to managerial performance. It can be interpreted that the higher the locus of control, the lower the influence of the characteristics of management accounting information on managerial performance. This is in line with the theory of planned behavior that explains behavior.

\section{References}

1. Ajzen, I., (1991), The Theory of Planned Behavior, Organizational Behavior and Human Decision Processes, 50, 179-211.

2. Ajzen, I., and Fishbein, M., (1975), Belief, Attitude, Intention, and Behavior: An Introduction to Theory and Research, 129-385, Addison-Wesley, Reading, MA.

3. Brownell, P. (1982), A Filed Study Examination of Budgetary Information and Locus of Control, Accounting Review, pp. 766- 777.

4. Bayuaji, H. (2009). Pengaruh Sistem Akuntansi Manajemen, Desentralisasi, dan Ketidakpastian Lingkungan Terhadap Kinerja Manajerial (Survey pada perusahaan tekstil di wilayah eks karesidenan Surakarta). Tesis Fakultas Ekonomi Universitas Muhammadiyah Surakarta.

5. Banker, R., G. Potter, and R. Schroeder. (1993). exporting manufacturing performance measures to worker: An empirical study. Journal of Management Accounting Research : 33 - 35.

6. Chenhall, R. H. and Morris, D. (1986). the impact Of stucture Environment and interdependence on the perceived usefulnes of management accounting sytem, The Accounting Review No 1 pp 16-35. 
7. Chia, Y. M. (1995). Decentralization, Management Accounting system Information Characteristic and Their Interaction Effects on Managerial Performance: A Singapore study, Journal of Business, Finance and Accounting, pp. 811-830.

8. Chenhall, Robert H., (2003). Management control systems design within its organizational context: findings from contingency-based research and directions for the future, Accounting, Organizations and Society, Elsevier, vol. 28(2-3), pages 127168.

9. Frucot, V., and Shearon, W. T. (1991), Budgetary Participation, Locus of Control and Mexican Managerial Performance and Job Satisfaction, The Accounting Review, Vol. 66, No. 1, January, pp. 80- 99.

10. Hellriegel and Slocum. (2011). Organizational Behavior 13th edition. South-Western Cengage Learning: USA.

11. Heller, F. A., and Yulk, G. (1969). Participation Managerial Decision-Making and Situational Variabels, Organizational Behavior and Human Performance.

12. Hansen and Mowen. (2000). Akuntansi Manajemen, Terjemahan Oleh : Ancella A. Hermawan, Jakarta : Erlangga.

13. Kaplan, R. 1990. Measures for Manufacturing Excellence. Boston, MA: Harvard Bussines School Press.

14. Miah, N. Z., and Mia. L. (1996). Decentralization, Accounting Control System and Performance of Government Organization; A New Zealand Empirical study, financial Accountability and Management, August, Vol. 12, No. 3, pp, 173-189.

15. Nugraeni. (2013). Desentralisasi Dan Sistem Pengendalian Akuntansi Ke Arah Kinerja Manajer Kantor Dengan Locus of Control Sebagai Variabel Moderating, Tesis S-2 Universitas Mercu Buana Yogyakarta.

16. Nazaruddin, (1998), Pengaruh Karakteristik Sistem Akuntansi terhadap Kinerja Manajerial, Jurnal Akuntansi dan Keuangan, Vol. 7, No. 2, Hal. 99.

17. Outley, D. T. (1980). The contingency theory of management accounting: Achievement and prognosis, Accounting, Organizations and Society, Elsevier, vol. 5(4), pages 413428.

18. Rahman, I. 2002. Hubungan Desentralisasi, Sistem Pegendalian Akuntansi dan Kinerja Unit Bisnis Organisasi Sekor Publik: Peran Locus of Control sebagai variabel Pemoderasi studi kasus PT Pos Indonesia (persero), Tesis S-2 Universitas Gajah mada Yogyakarta.

19. Suartana, I. W. (2011). "Akuntansi Keperilakuan Teori dan Implementasi". Yogyakarta : Penerbit Andi.

20. Supriyono, R. A. (1992), Akuntansi Manajemen I, Konsep Dasar Akuntansi Manajemen Dan Perencanaan, Edisi Kedua, Penerbit BPFE, Yogyakarta.

21. Watson, T. (2015). Effective Managers: Your Critical Link To Succesful Strategy Execution. Survey Report, TW-NA-2014-37760.

22. Bedeian, Z. D. A. G., R. F. (1991). Organizations. Theory and Design. Dryden Press, Usa. 